\title{
SO ORDERED: A Textual Analysis of United States' Governors' Press Release Responses to the COVID-19 Pandemic
}

\section{Taylor S. Voges ${ }^{1}\left[\right.$ and Matthew T. Binford ${ }^{1}[1$}

1. Grady College of Journalism and Mass Communication, University of Georgia, Athens, GA, USA

\section{ABSTRACT}

The COVID-19 pandemic presents a unique environment from which each individual state, in the United States, has been forced to address their publics. In order to understand how each state has engaged with this pandemic, a textual analysis of each state's governor's first press release was conducted; five thematic trends were identified. Through use of the social trust approach to risk communication and the contingency theory of strategic conflict management (using external threat variables), the implications of these press releases are discussed.

KEYWORDS: risk communication, contingency theory, textual analysis

The year 2020 will perhaps be best remembered as the first year in which the novel coronavirus, COVID-19, began to spread widely around the world. By the middle of 2020, the United States had become the global epicenter for the novel coronavirus pandemic with millions of confirmed cases and hundreds of thousands of deaths as a result of the virus (Johns Hopkins, 2020). Given the rapid growth of the coronavirus and the staggeringly high numbers of cases and deaths, it is important to briefly recount what the pandemic looked like in its earliest days in the United States.

It is certainly possible that the virus had been silently spreading in the United States before the first verified case of COVID-19.

CONTACT Taylor S. Voges (D . E-mail: taylor.voges@uga.edu • Grady College of Journalism and Mass Communication • University of Georgia • 120 Hooper Street • Athens, GA 30602, USA 
However, the first confirmed case of COVID-19 in the United States that the public was made aware of was reported in Seattle, Washington, in mid-January 2020 (McNamara, 2020). The arrival of the novel coronavirus in the United States was not initially met with widespread panic. Though relatively soon after, state governors begin to formally declare states of emergency in response to rising cases, beginning with Governor Jay Inslee of Washington on February 29, 2020. Notably, February 29, 2020, the day Washington State declared a state of emergency was also initially believed to be the first coronavirus death in the United States after a patient died in Washington (Acevedo \& Burke, 2020).

This death in Washington, while it was the first COVID-19 death to be reported to the public, was not actually the first death from the new virus. In April of 2020, medical examiners in California posthumously identified that a person in Santa Clara County California died due to complications from the novel coronavirus on February 6, 2020, which is several weeks before the patient in Washington (Chappell, 2020). After Washington became the first state to declare a state of emergency, other states quickly followed suit. By mid-March nearly all 50 states had declared a state of emergency, and on March 13 President Donald Trump declared a national state of emergency (FEMA, 2020). On March 13-the day a national state of emergency was declared-the Johns Hopkins Coronavirus Resource Center noted that there were a total of 2,157 cases in the United States. The last governor to formally declare a state of emergency for his state was Gov. Jim Justice (R) of West Virginia who declared a state of emergency on March 16. This issuance of a state of emergency was done in West Virginia before the state had even seen its first confirmed case of COVID19, though the first person in the state did test positive the next day, on March 17 (West Virginia Department of Health and Human Resources, 2020). As these events demonstrate, the United States' governors dealt with the initial effects of the coronavirus before a national state of emergency was declared. As such, the interest for this study is state governors as they were the initial actors and leaders during the pandemic's early stages. 
At its core, the United States is a constitutional federal republic, which means that there is both a national governing system that oversees the collective 50 states and local governing bodiesboth state and municipal (U.S. Government, n.d.). The leader of the national government is the United States President while the leader of the state government(s) is the governor. Each United States Governor acts as a leader to his or her state, so constituents look to their governor for guidance and leadership. To illustrate, governors tend to respond differently to threats (e.g., Hurricane Harvey), but these previous threats were more centralized to certain locations. The COVID-19 pandemic holistically hit the United States-and the world-but it was still up to the different levels of government to lead. Thus, it becomes important to understand the United States' state governors' early communications with the public. The very beginning of the pandemic in the United States is briefly outlined from the first reported case to the day the last state governor declared a state of emergency.

While one can consider that governors acted quickly to declare states of emergencies in efforts to prepare their states for the novel coronavirus, it is also worth noting that this was a general time of confusion for many people as to what the proper response to COVID-19 was. For example, by the summer of 2020 it was widely accepted among the scientific community that wearing a mask was one of the most effective ways of slowing the spread of the novel coronavirus (CDC, 2020). However, this message was not always one made clear to the public. At one point in early March, Surgeon General Jerome Adams said in an interview that wearing masks can increase one's chances of getting the novel coronavirus (Schreckinger, 2020). This example was brought up not to show a shortcoming of communication from government officials, but rather to highlight how confusing the earliest days of the COVID19 pandemic were as the public and the scientific community alike struggled to understand this threat.

It is important to unearth as many insights as possible about initial communications from those in positions of power, such as state governors, to better understand how novel threats should 
be communicated. State governors are responsible for decisions about coronavirus policy, but also are responsible for how that policy is communicated to the public. The communication coming from their offices not only drives discourse in their state, but can also impact how the novel coronavirus is perceived nationwide. Provided that initial communication sets the tone for the total communications about an issue, it is, therefore, important to review what initial communications were made. Thus, a review of each state's governor's initial press release was conducted to glean insights into the risk management strategies taken during the early stages of the COVID-19 pandemic.

\section{Literature Review}

This study examines the communication about the coronavirus pandemic through a textual analysis of how each state's governor has approached the COVID-19 virus in a press release-situated within risk communication framework and the contingency theory of strategic conflict management.

\section{Risk Communication}

Risk communication is a broad field of communication researchone that is connected to various fields like public relations, communication management, and risk management. Risk management, as defined by Stern and Fineberg (1996), includes "things, forces, or circumstances that pose danger to people or to what they value" (Stern \& Fineberg, 1996, as cited in Rhee, 2008). Indeed, public relations is at times considered an extension of strategic management of risks (Rhee, 2008). Organizations can use public relations as a way to develop risk management strategies and communicate with stakeholders during these risky times (Rhee, 2008). Effective risk management requires communication practitioners to help stakeholders understand how the organization made a rational decision concerning the risk and how the decision upholds both the stakeholders' and organization's ideas, interests, and values (Brummette \& Sisco, 2018).

Public relations practitioners, and any other type of risk management team, need to be aware of the differences and prepare 
strategies that are tailored to each situation. As part of this preparedness, scholars have worked to develop various approaches to risk communication, such as the mental models approach (e.g., Morgan et al. 2002), the convergence communication approach (e.g., Rogers \& Kincaid, 1981), the three-challenge approach (e.g., Rowan, 1991), the hazard plus outrage approach (e.g., Sandman, 1987), and the social trust approach.

Each of these approaches center around a different risk communication core. For mental models, the core is found in cognitive psychology and is used to (1) help identify to whom the risk communication should be directed to and (2) the processing of the risk communication (Lundgren \& McMakin, 2013). The mental models approach is used to develop audience-centered perspectives on different risks. In contrast, the convergence communication approach views risk communication as a long and iterative process that is constantly based around the organization communicating and the audience it is communicating with-values and preferences (culturally or otherwise) constantly affect the process (Lundgren \& McMakin, 2013).

The approach of interest, however, is the social trust approach to risk communication. This approach developed within an area of social science research interested in a person's-or an audience'strust in an organization, such as a governmental institution. Cvetkovich and Winter (2002) worked to develop this approach through projects that he worked on for the United States, such as with the United States Department of Agriculture. The core of the social trust approach is based around values, evaluations, and judgments (Cvetkovich \& Winter, 2002). Fundamentally, having trust is seen as a way to reduce complexities and complications; the trust is fluid, however, and has the potential to be broken (Cvetkovich \& Winter, 2002). Cvetkovich and Winter propose that trust is part of an evaluative process-one that helps a person make judgments. This iteration of trust is fundamental but incomplete. Trust goes beyond having confidence in another person or in an organization. Indeed, trust is made up of inferences-both seen and unseen-about another's motives, attitudes, and beliefs (Cvetkovich \& Winter, 2002). Trust built on what is seen (i.e., actions) provides the evaluator with inferences about the actor's 
attitudes and beliefs just as much as trust that is built on what is unseen-something that happened at a distance with no obvious opportunity for the evaluator to directly observe (Cvetkovich \& Winter, 2002).

Beyond what is seen and what is unseen, trust is also built on the congruence of values (Cvetkovich \& Winter, 2002). The evaluator takes personal values and places them against the entity being evaluated. Similar values for the evaluator and the evaluated entity have shown to lead to higher social trust (Earle \& Cvetkovich, 1997). Further, the type of situation at hand-environmental risk versus a health risk-helps determine the type of values at play and to what extent those values matter (Cvetkovich \& Winter, 2002).

Through this approach to social trust, it is apparent that audiences use various processes to judge an organization. Social trustfrom the audience perspective of an organization-is founded in the people's ability to understand the organization's goals and values (Lundgren \& McMakin, 2013). If an audience member has negative attitudes toward an organization, any negative information they encounter regarding the organization will only work to reinforce the distrust toward the organization (Lundgren \& McMakin, 2013). The reverse is also true: positive attitudes will be reinforced when the audience encounters positive information about an organization, which results in increased trust. Indeed, social trust can be thought of as one of the most important aspects of risk communication (Lundgren \& McMakin, 2013).

The social trust approach ultimately sets the foundation for the strategic conflict management of risks, specifically that of COVID-19. As discussed, audiences use trust as a way to evaluate and judge an organization's communication-or the organization's presentation of a risk. The contingency theory of strategic conflict management, in turn, presents a number of variables that organizations use to help them determine the best stance to take during conflicts and times of uncertainty (Cancel et al., 1997). These perspectives are taken in tandem because the social trust approach to risk communication demonstrates how imperative it is for organizations - such as governmental entities - to understand how their social trust standings are determined by their audiences. Further, the contingency theory of strategic conflict management views 
stance-making as fluid and depending on an organization's evaluation of the situation. In this case, the situation-COVID-19-is viewed through the contingency theory because it is imperative to see how the local leaders of the United States presented the issue to their respective constituents.

\section{Contingency Theory}

Contingency theory, often referred to as the "it depends" theory, attempts to account for real-world complexities (Pang et al., 2016). The core of contingency theory is the continuum, which attributes the flexibility organization's use when determining a stance on an issue; the continuum ranges from pure advocacy to pure accommodation (Cancel et al., 1997). The stance an organization is said to take depends on a variety of factors, 86 in total, and how such factors influence organizational stance along the continuum (Cancel et al., 1997). The contingency theory allows for a specific analysis of predetermined variables (i.e., those identified by Cancel et al., 1997) and provides researchers with the opportunity to analyze organizational stances in accordance with both the continuum and the variables.

It is important to note, however, that an organization's stance is not a legitimate enactment of all 86 variables at once; instead, the contingency theory works to demonstrate how certain types of variables may be more salient than others during specific situations (Cancel et al., 1997). Based on this logic, researchers can investigate specific types of variable constructs, such as with Jin et al. (2015). They propose five subgroups out of the total five theoretical constructs in order to determine how the grouping of variables outweigh each other in terms of organizational decision-making.

Constructs are subgroups that contain more defined groupings of variables (Jin et al., 2015; Reber \& Cameron, 2003). Within these constructs are variables that are considered influential based on the contingency theory (Cancel et al., 1997). Based on the profound number of variables, it is typical for researchers to choose which variables they consider important to their research. Thus, for the novel coronavirus scenario, a focus on a subset of external variables is used in order to understand how governors 
strategically communicated to their constituents about the risk of the novel coronavirus.

\section{External Variables}

The external variables are split into five subgroups: (1) threats, (2) industry environment, (3) general political/social environment/ external culture, (4) the external public, and (5) issue under question (Jin et al., 2015). Each external variable subgroup includes a list of specific variables-the specific variables of interest are within the issue under question theoretical construct. Issue under question is specifically of interest-as COVID-19 constituted the active issue. Under issue under question are the variables issue size, issue stake, and issue complexity.

Issue Under Question. The variables proposed within issue under question include issue size, issue stake, and issue complexity. These variables have been tested in various studies, such as with Dant and Schul (1992), and later included in the contingency theory's list of variables as those considered influential regarding organizational stance decision-making (Cancel et al., 1997). An issue's size encompasses how an actor defines the scope of the issue itself; it is further considered important as it helps develop norm responses that will later serve as precedents for the issue itself (Dant \& Schul, 1992). However, it is important to acknowledge the ramifications of precedent-setting for an issue (Dant \& Schul, 1992). An issue's stake refers to what threats, gains, or losses the issue holds over those it could potentially affect (Dant \& Schul, 1992). Further, stake is used to better distinguish what is meant by issue size with the former referring to the implications of the issue and the latter referring more to the scope of the issue. An issue's complexity is a variable that has the potential to influence conflict management actions (Dant \& Schul, 1992). It is proposed that issues with high complexity typically invoke solution tactics that include the use of politics and bargaining while issues with low complexity are typically solved by using problem-solving and persuasion tactics (Dant \& Schul, 1992). Thus, it can be inferred that issues with high complexity result in communication tactics that are generally more abstract. 
Given the relative unknowns regarding the COVID-19 virus issue (both at the time of the press releases and after), it is prudent to understand how each state's governor chose to describe the issue to their respective constituents. Further, an analysis of governor messaging provides general insights into each state's chosen risk communication tactics. Thus, the following research question is posed:

RQ: How does each state's governor refer to the following external factors-issue size, issue stake, issue complexity-in their initial COVID-19 press release?

\section{Method}

This study employs a qualitative textual analysis approach to understand the implications of each state's governor's response to the COVID-19 pandemic. Specifically, a textual analysis allows for a thematic and systematic analysis of selected texts-the intent being to garner a deeper understanding of the population by looking for commonalities and underlying trends (Fürsich, 2009). Thus, this study employs this research technique and examined each state's governor's first press release response to the COVID19 pandemic. Each press release was selected based on specific criteria: the release was the first mention of the pandemic and the release came from the governor's office. This study did not focus on releases put forth by other state departments, such as the health department. The reason for doing so is that the governor is a figurehead typically known to the public, interacts more consistently with the public, has the authority to issue decrees, and is an elected official. Thus, 50 press releases were analyzed-one for each statefor thematic elements.

This textual analysis sought to analyze the first public press releases that each state governor released dealing with the novel coronavirus pandemic in 2020. To find this information, the researchers went to each state government's website and looked for press release archives. Once found, the researchers searched for press releases mentioning COVID-19 or the novel coronavirus pandemic. The researchers then looked for the earliest substantive press releases that included information about the state 
government and its perceptions of the novel coronavirus. The dates of the first press releases about the COVID-19 pandemic from the state governors ranged from January 27, 2020 (Connecticut, Lamont-D) to March 17, 2020 (Wyoming, Gordon-R).

Notably, many states' first official press releases simply were statements saying that reporters could expect more information at a later predetermined time. These press releases were not considered substantive and were not included in the sample. Instead, when the researchers found these as the first official coronavirus statement they used the next earliest official press release. For Arizona, the first press release from the state's governor's office (Ducey-R) was a video conference, so the transcription for it was analyzed. The press releases analyzed for this study is holistic-all states' governor's press releases were included in the analysis.

\section{Results}

After reviewing each state's governor's initial COVID-19 press release $(n=50)$, the analysis revealed four persistent themes evidencing the relative unknowns regarding the beginning of the COVID-19 pandemic as seen in the United States. These themes include COVID-19 contraction risk reassurance, a bolstering of state actions, citizen readiness actions, and COVID-19 case travel scapegoating. Each theme directly relates to the theoretical foundations of social trust and the contingency theory of strategic conflict management. The press releases were specifically from the governor's office and averaged out to around one to two pages each. A deeper analysis of the press releases reveals how little state governments actually knew about COVID-19, which suggests that their relative blasé attitude may have been attributed to the general sense of uncertainty many felt while the virus spread across the United States.

\section{COVID-19 Contraction Risk Reassurance (Issue Size and Complexity)}

Throughout the press releases, it was common to find verbiage that held tones of reassurance. The reassurance, however, came in two 
different forms-in either a reference to the low number of cases or as an indirect downplay of the novel coronavirus itself.

\section{Number of COVID-19 Cases (Issue Size)}

State governors used the platform as a place to provide citizens with the number of COVID-19 cases, which typically totaled out to less than 10 (at the time of the press release): “. . . there are no current diagnosed cases in the state, Montana ... " (Gov. Bullock, MT-D); "There are no confirmed cases of COVID-19 in the State of Nevada” (Gov. Sisolak, NV-D); “. . . while no one in Utah has yet tested positive for COVID-19 ..." (Gov. Herbert, UT-R). These instances indirectly acknowledge the presence of COVID-19 cases elsewhere, but they double as reassurances. Each state's respective citizens can take the lack of cases to mean that the state is successfully keeping the virus out of the state instead of taking the lack of cases as meaning that the virus has not yet reached the state.

Further instances of reassurances came from describing the well-being of a previously sick individual. Indeed, some governors would reference how well a sick individual is doing-thus providing citizens with hope. Governor Cooper (NC-D) stated in a press release, ". . . the person is doing well and is insolated at home." Additional states provided similar statements, including Governor Cuomo (NY-D) who released a statement saying, "the patient has respiratory symptoms, but is not in serious condition and has been in a controlled situation since arriving to New York." These statements came with assumptions that states had control over the contracted cases-again lending to the reassurance of their citizens. This type of reassurance can potentially be construed as accidental over-reassurance regarding the severity of the novel coronavirus.

\section{Downplaying COVID-19 (Issue Complexity)}

The time frame of these press releases-spanning from late January to the middle of March in 2020-demonstrates the beginning attempts at communicating about a virus that is virtually unknown. Some of these communication attempts resulted in a downplay of the novel virus itself-along with its severities. Governor Pritzker (IL-D) released a statement that included the following: 
The immediate health risk to the state remains low. While the latest available information suggests that person-to-person spread will continue to occur and additional cases are likely to be identified in the United States, most cases of COVID-19 cause a mild illness. In very rare cases people infected with the virus have died. Additionally, to date, data shows that children are less likely to become ill. (Gov. Pritzker, IL-D)

Other governors used similar language in their initial press releases including-but not limited to-Governor Beshear (KYR), ". . . even though Kentuckians are at low risk for this virus ..."; Governor Little (ID-R), “. . . the individual risk for coronavirus in Idaho is still low . . ."; Governor DeSantis (FL-R), “. . . the threat COVID-19 poses to Florida remains low ..."; Governor Mills (MA-D), “. . . no cases of coronavirus in Maine as of today, and the risk to our state remains low. ..." These instances provide their stakeholders with an indirect downplay of the virus's potential severity.

Governors-from multiple states-provided their constituents with verbiage that indirectly downplayed the virus's severity. Similarly, the inclusion of the number of cases-or even the lack of a COVID-19 case in a state-contributed to a reassured public. Even though these press releases were released in the early stages of the COVID-19 pandemic, the "low risk for the virus" statements indirectly reassured citizens far more than necessary.

\section{COVID-19 Case Travel Scapegoating (Issue Stake)}

States repeatedly mentioned that those who should most be concerned with contracting the novel coronavirus were those who had recently traveled to places that were thought to be COVID-19 hotspots. Many governor's offices such as Kelly's (KS-D) specifically noted that individuals should only isolate if they have:

Recently traveled to China, Iran, Italy, Japan and South Korea and have developed fever with lower respiratory symptoms including cough and shortness of breath within 14 days of your travel, or have had contact with someone with a laboratory-confirmed case of COVID-19. (Gov. Kelly, KS-D) 
Another instance of a state governor's office discussing citizens traveling as the way the novel coronavirus is spreading in their state comes out of Indiana where they note that,

\footnotetext{
“This morning, Gov. Holcomb and the Indiana State Department of Health confirmed the first case of coronavirus in a Marion County resident with a recent history of travel to a Boston event tied to several cases in other states." (Gov. Holcomb, IN-R)
}

Though many governors' offices noted the dangers of traveling to countries that were coronavirus hotspots, or in some cases even states that were coronavirus hotspots, most downplayed the possibility of person-to-person transmission within their own states. Few states specifically mentioned the possibility that the novel coronavirus could be widely spread from person-toperson among those who had not recently traveled. Connecticut is one of the few states that noted that there was a significant danger that COVID-19 could be spread between individuals who had not been to China or another coronavirus hotspot. Instead the governor's office in Connecticut hypothesized how the virus could be spread between individuals noting that this virus is similar to SARS and MERS:

When person-to-person spread has occurred with MERS and SARS, it is thought to have happened via respiratory droplets produced when an infected person coughs or sneezes, like how influenza and other respiratory pathogens spread. Spread of SARS and MERS between people has generally occurred between close contacts. (Gov. Lamont, CT-D)

\section{Bolstering of State Actions (Issue Complexity)}

Governors used these press releases as an opportunity to show how well the states were handling the COVID-19 virus. These instances typically came through in the form of state preparedness or in referencing how other states were faring in comparison to their own. Governor Kemp's office (GA-R) released a statement that included the following, ". . . fortunately, the Peach State boasts some of the world's most advanced healthcare experts . . . to make sure that 
we are ready for any scenario." Governor Edwards (LA-D) stated, ". . . Louisiana has been preparing since the COVID-19 outbreak in mainland China." Governor Ige (HI-D) mentioned a specific healthcare liaison and professed his faith in this expert's ability. Notably, Governor Herbert (UT-R) put Utah's number of cases (at the time, zero) against that of the neighboring states. These instances demonstrate how different states used their preparedness tactics and overall virus readiness as a way to demonstrate competency. Governor Sisolak (NV-D) provided the following statement:

I know that took a long time, but I want Nevadans to understand the large-scale collaboration taking place across the state, and the commitment of each of the individuals who have been working on this issue for months. They represent hundreds of more Nevadans in their respective fields and regions they serve-all waking up every day with the same mission: to prepare and protect the health and safety of the public. (Gov. Sisolak, NV-D)

Like many others, this demonstrates how governors attempted to provide citizens with evidence about how the situation is being taken seriously and is given much thought. Essentially, these statements applauded their own efforts.

Many initial COVID-19 press releases included mentions of a new state task force-including mentions of the highlyqualified members. Governor Abbot (TX-R), Governor Gordon (WY-R), Governor Scott (VT-R), Governor Lee (TN-R), and Governor Bullock (MO-D) are among the governors that cited their coronavirus task force efforts. However, some of these announcements only included the development of a task force (and potentially a list of experts) with little mention of the task force purpose beyond the coronavirus, ". . . to help us be even better prepared, this group of experts will work closely with me and my administration, along with local, state, and federal agencies as we continue to monitor any potential developments" (Gov. Lee, TN-R).

\section{Citizen Readiness Actions (Issue Stake)}

Many of the sample texts included basic instructions for citizens as to how they can protect themselves from COVID-19. A recurring 
message found in many of the press releases was that the best method for protecting oneself was similar to how one would protect themselves from the flu: "the best way to prevent infection is to take precautions to avoid exposure to this virus, which are similar to the precautions you take to avoid the flu" (Gov. Abbott TX-R). In addition to abstractly telling people to protect themselves in the same way one would protect themselves from the flu it was common for states to have a bullet point list of concrete steps residents could take to best protect themselves and their families, such as this partial statement from the Virginia governor's office:

Although COVID-19 is not spreading in Virginia and the risk here is low, officials said Virginians can take precautions to prevent the potential spread of this disease:

- Avoid close contact with people who are sick.

- Avoid touching your eyes, nose, and mouth with unwashed hands.

- Wash your hands often with soap and warm water for at least 20 seconds.

- Use alcohol-based hand sanitizer that contains at least 60 percent alcohol if soap and water are unavailable.

- Cover your cough or sneeze with a tissue, then throw the tissue in the trash.

(Gov. Northam VA-D)

This list from the governor's office of Virginia is one example of the bulleted lists of COVID-19 precautions found in the press releases.

This concrete language can be very important so that people have simple and easy to follow instructions; however, it should be noted that often the language states used to give these instructions often invoked feelings of condescension-as if a parent were speaking to a child. Most notably, before listing some of the ways Nevadans can slow the spread of coronavirus the governor's press release stated, "I realize this is going to sound a bit like the advice I used to give my daughters when they were little, but please bear with me" (Gov. Sisolak NV-D).

\section{Discussion}

While the lack of information about a novel virus is to be expected at the onset of a pandemic, the communication tactics 
and language used by governors in their initial COVID-19 press releases did not appropriately set the tone for what would become a global pandemic. Cvetkovich and Winters (2008) provides ample logic and reasoning behind social trust: the evaluator-in this case various clusters of American constituents-process and ultimately judge the entity being evaluated-the U.S. governors. Provided the results, it is apparent that the U.S. governors' foundation for addressing the COVID-19 pandemic was incomplete.

Given the rather sporadic types of press releases, it is unclear as to whether or not a majority of the states had a set communication risk plan in place. Indeed, less than 10 states referred to the overall issue complexity of the issue and, when they did refer to the issue complexity, the statements were more overreaching than definitive. Governors did not use the press release platform to emphasize the unknown elements of this novel coronavirus. Instead, the press releases heavily reiterated the number of cases (or the lack thereof) and the low probability of the coronavirus reaching their specific state.

In references to the low risk, governors chose to provide either comparisons or mentions of the virus in places outside of their specific state. This specificity is reflective of the external variable size-governors reflected on the issue's size by using other locations' interactions with the virus as a way to either reassure their citizens or downplay the risk to the immediate state. Thus, the issue size is present but the legitimacy of the issue size as relevant to the actual state at hand was considered minimal in virtually all press releases. The contingency theory encapsulates organizational stance movement as organizations deliver communications (Cancel et al., 1997; Jin et al., 2015) and, looking at the initial COVID-19 press releases, it is clear that governors used the issue size as a way to advocate for their own thoughts on the novel coronavirus. Governors referred to the virus and its impact as if in a vacuum that included only the state in question. Thus, COVID-19's issue size was indirectly used to reassure rather than as a platform for providing citizens with communication about potential unknowns.

An issue's stake helps establish how involved those affected will become with the assumption that higher stakes lead to higher levels of involvement (Dant \& Schul, 1992). In terms of stake as 
related to the novel coronavirus, virtually no governors provided information that referred to tangible losses, such as loss of life. It is important to note that the number of cases and deaths had not reached the thousands, as they had by midway 2020. The few press releases that mentioned the known symptoms of COVID-19 also typically positioned the symptoms against flu symptoms. This choice to capture the then-known symptoms of COVID-19 against the flu symptoms points to stance choices are further reflective of issue stake. Likening novelty to something known may be helpful, but the downside of such an association is that the issue's stake is too likened to the flu. While the COVID-19 pandemic was an increasingly ongoing and unprecedented event, the social trust approach of risk communication blatantly describes the fallout organizations face: audience members who have positive attitudes toward the organization will use positive information to reinforce their attitudes and trust in that organization (Cvetkovich \& Winter, 2002). However, the reverse is also true, which means that state constituents who felt that their governor's initial response to the pandemic was lacking were likely to have a lowered level of trust as a result of the press release. Regardless, the press releases did not provide definitive and tangible stakes about the novel coronavirus issue. There was an intense lack of precaution statements about COVID-19 and what the disease could do to a society.

While it is impossible to predict the future with precise certainty, the complete disregard for any mentions about the novel coronavirus's potential severity is astounding. Governors chose to reiterate the apparent "low risk" of COVID-19 with little mention of the ramifications of the disease itself. This apparent "low risk" is a direct reference to the issue's stake and, provided that these press releases are from the states' governor's offices, offered constituents guidance on how to view the virus. The strategic language used in the press releases attempted to mitigate uneasy feelings and reassure stakeholders about COVID-19. This reassurance can be reflexive of an attempt to gain or maintain social trust between the state and the people, but the long-term consequences of these stance choices were not obviously considered.

Based on the analysis, it is apparent that the press statements made little mention of the novel virus's complexity, which may 
be attributed to the complete lack of information about what is at stake due to the virus. Governors prioritized reassurance of stakeholders over communication about an unknown virus as seen through the pattern of reassurance language present in virtually every press release. When pitted against the lack of information on the complexity of the virus, it is clear how governor offices chose to placate their citizens instead of admitting to the general public the unknowns about the virus. Communication about an issue's stakes, as described and researched by Dant and Schul (1992), are connected to the level of involvement by way of the message receivers. Thus, it can be inferred that the dismissal of the novel virus complexity informs communication about the potential stakes and-since the stakes were virtually never mentioned-influenced how citizens determined their own levels of involvement for the coronavirus issue. While contingency theory holds that a number of factors influence an organization's stance, it is important to note the weight of the issue itself is something that the governors did not emphasize in their press releases. It is suggestive then that other factors influenced the decision-making for each state's stance on the COVID-19 issue.

The COVID-19 case reassurance theme was prevalent in most to all press releases - demonstrating how governors used these initial communication efforts to reassure and placate their constituents. While it is important to not incite mass panic upon the onset of a novel virus, the level of reassurance found in the press releases inferred that the virus was not something that citizens should be concerned about. The language used had the opposite effect of a mass panic. It provided citizens with comfort, a sense of hope, and potentially gave citizens the go-ahead to dismiss any real concerns about the severity of the virus. Governors typically included the number of cases in their states-and at the time most were at zero or one-and then proceeded to use language that inferred that the virus would not reach the state or was contained by way of state preparedness measures. Despite these measures, virtually no statements then referenced the complexities surrounding a novel virus. This attempt to reassure constituents lends to conversations of social trust. The references to personal, state connections (i.e., "Nevadans" or "Arizonians") demonstrates how the governors and 
state entities are attempting to provide constituents with common ground and values to rally around. The appeal to immediate state safety is a similar appeal to congruent values-assuming that the constituents are invested in their state actions. Though the values important for a situation are in part determined by the situation (Cvetkovich \& Winter, 2002), it is clear that the states attempted to offer their constituents with values and reassurances that would work in favor of social trust.

Perhaps unsurprisingly, the majority of governors used the initial COVID-19 press releases as a place to bolster state efforts and actions. The theme, bolstering state actions, demonstrated how some states used these communication efforts as an avenue to showcase all their great work (e.g., taskforce creations and convening with politicians or doctors). It is important for the public to know what their respective states are doing to work against the impact of the novel coronavirus, but the manner in which the governors presented these efforts came off as prideful and boastful. Indeed, some states even used other state efforts as a comparison against their own. These references implied that some states were acting better than others when COVID-19 was concerned. Unfortunately, this contributes to feelings of complacency or a false sense of security as many governors made statements that include variations of the phrase "low risk for Kentuckians" (with a substitute for the appropriate state). While some of the press releases included information about the efforts each state made toward the fight against the coronavirus, it is clear that some of these bolstering statements were made to make citizens proud of how well their government was handling the situation.

COVID-19 case travel scapegoating was a trend for those states who reported a COVID-19 case in their state. It was apparent that governors wished to provide an explanation as to how these affected individuals contracted the virus and such efforts included using travel as the necessary scapegoat. This both worked to distance the infected individual(s) from the measures the state took to minimize virus contraction and acted as a platform for the states to tell their constituents how well their preparedness and testing abilities worked. Again, this trend demonstrates how governors assuaged general public concerns about COVID-19. Indeed, it is 
human nature to be curious about such matters, but the way the statements were written made it seem like the main way to contract the virus was through travel-specifically travel to certain areas of the world.

When it came to addressing how citizens should act, some states either included a list of actions they likened to flu prevention measures or forewent including preventative measures entirely. The analysis further demonstrated how some statements included language that came off as condescending or as if speaking to a child (e.g., Gov. Sisolak, NV-D). Many governors reiterated the importance of handwashing by reminding their constituents of when they (the constituents) first learned to wash hands. Some mentioned the importance of good hygiene, but they failed to mention what this might entail. This level of condescension is appalling and provides insight into how these elected officials see their constituents. On top of the general personal health comments, the officials urged their constituents to treat the threat of this virus as either the flu or another natural disaster (e.g., Gov. Wolfe, PA-D). Within the example press releases, governors urged citizens to prepare with weeks' worth of supplies-stockpiling over-the-counter drugs, food, and water. Taking the press releases in totality, however, it becomes clear how some of the information and instructions seem contradictory-with no mention of the issue's stakes or complexity but asking citizens to prepare on a natural disaster level.

Further, it can be inferred that the reassurance found in the press releases contributed to the unintentional downplaying of the COVID-19 virus itself. Indeed, the highest executive elected officials-de facto leaders-refused or failed to admit the unknowns about COVID-19.

Governors are literally the highest elected official a state can have and their statements make local, state, and federal news cycles. Their statements have the potential to reach millions of Americans, yet their single-minded attention toward public reassurance and state pride resulted in a drastic overlook for citizen welfare. Each governor declares an oath that requires them to uphold the office of the state and its citizens and such duty was lacking during the early coronavirus times. Despite the fact that some governors even reiterated their commitment to safeguarding 
citizens, omitting statements that referred to the issue's complexity and potential stake hurt their constituents. Further, it is argued that state governors worked to maintain social trust with their citizens, but given their ultimate stance choices-as seen through depictions of COVID-19's size, stake, and complexity-opened them up to scrutiny. A hyper focus on immediate reassurancean attempt to speak to constituents through their predetermined social trust contract-omitted the possibility that more, new information about the COVID-19 pandemic might change governors' initial stances.

\section{Limitations and Future Directions}

This study only looks to state government press releases specifically from each governor's office. The analysis focuses solely on analyzing the press releases, but given the nature of the results, it is important for future research to use ethical frameworks to gain insights into the moral rightness of these press releases. Additionally, future research can-and should-look to early press releases from state health departments in order to understand how health professionals (1) understood the COVID-19 pandemic and (2) communicated that understanding to stakeholders. Health professionals are increasingly being looked to as thought-leaders, so an analysis of what and how these communications manifest is of utmost importance.

\section{Conclusion}

The COVID-19 issue was a dynamic and ongoing situationespecially during the onset of the global pandemic-even though few governors referred to it as such. Given their prestigious powers and elected status, it is assumed that governors act with the best interest of their constituents at heart. However, the insights illustrate how the governors' attitudes toward the complexity of this novel virus set the tone for their constituents-how self-serving some of the communications was-with states applauding their lack of cases and their efforts to keep the virus out of their states. Despite their efforts, COVID-19 ended up reaching all 50 states 
and infected millions of people (Johns Hopkins, 2020). Months into the outbreak, it is apparent how confused, uncertain, and unwilling to trust some groups of people are-perhaps because of the tone their governor set at the beginning of the pandemic. Risk management plans are lacking. It is impossible to predict natural disasters, but it is possible to prepare for them through both actions and communication plans. Initial communication efforts need to better include information relevant to constituents with acknowledgments of shortcomings tied with their communications about state actions. While it is unknowable whether or not better initial communication by way of each state's governor's office would affect the outcome of the COVID-19 pandemic in the United States, it is apparent that there is work to be done in terms of risk communication and state priorities.

\section{ORCID}

Taylor S. Voges () https://orcid.org/oooo-0003-2702-6836

Matthew T. Binford (1) https://orcid.org/000o-0002-6352-3584

\section{References}

Acevedo, N., \& Burke, M. (2020). Washington state man becomes first U.S. death from coronavirus. https://web.archive.org/ web/20200229181306/https://www.nbcnews.com/news/ us-news/1st-coronavirus-death-u-s-officials-say-n1145931

Brummette, J., \& Fussell Sisco, H. (2018). Holy guacamole! Framing and the chipotle contamination issue. Journal of Communication Management, 22(3), 280-295. https://doi. org/10.1108/JCOM-08-2017-0085

Cancel, A. E., Cameron, G. T., Sallot, L. M., \& Mitrook, M. A. (1997). It depends: A contingency theory of accommodation in public relations. Journal of Public Relations Research, 9(1), 31-63. https://doi.org/10.1207/s1532754xjprro901_02

CDC. (2020, July 3). Coronavirus (COVID-19) frequently asked questions. Retrieved July 15, 2020, from https://web.archive. org/web/20200715004220/https://www.cdc.gov/coronavirus/ 2019-ncov/faq.html 
Chappell, B. (2020). 1st Known U.S. COVID-19 Death Was Weeks Earlier Than Previously Thought. Retrieved July 15, 2020, from https://web.archive.org/web/20200715145402/ https://www.npr.org/sections/coronavirus-live-updates/ 2020/04/22/840836618/1st-known-u-s-covid-19-death-wason-feb-6-a-post-mortem-test-reveals

Cvetkovich, G. T., \& Winter, P. L. (2002). Social Trust and the Management of Threatened and Endangered Species: A Study of Communities of Interest and Communities of Place. USDA Forest Service Research Paper PSW-RP-247.

Cvetkovich, G. T., \& Winter, P. L. (2008). The experience of community residents in a fire-prone ecosystem: A case study on the San Bernardino National Forest. https://doi.org/10.2737/ psw-rp-257

Dant, R. P., \& Schul, P. L. (1992). Conflict Resolution Processes in Contractual Channels of Distribution. Journal of Marketing, 56(1), 38-54. https://doi.org/10.2307/1252131

Earle, T. C., \& Cvetkovich, G. (1997). Culture, cosmopolitanism, and risk management. Risk Analysis 17(1): 55-65. https://doi. org/10.1111/j.1539-6924.1997.tboo843.x

FEMA. (2020). COVID-19 Disaster Declarations. Retrieved July 15, 2020, from https://web.archive.org/web/20200716104244/ https://www.fema.gov/coronavirus/disaster-declarations

Fürsich, E. (2009). In Defense of Textual Analysis. Journalism Studies, 10(2), 238-252. https://doi.org/10.1080/1461670080 2374050

Jin, Y., Pang, A., Cameron, G. T., Reber, B. H., \& Cropp, F. (2015). Mapping Contingency factors in public relations practice: A conjoint approach to the Contingency Theory of Strategic Conflict Management, paper presented at the European Public Relations Education and Research Association (EUPRERA), October 1-3, 2015, BI Norwegian Business School, Oslo.

Johns Hopkins. (2020). COVID-19 Dashboard by the Center for Systems Science and Engineering at Johns Hopkins University. Retrieved July 14, 2020, from https://coronavirus.jhu.edu/ map.html 
Lundgren, R. E., \& McMakin, A. H. (2013). Risk communication a handbook for communicating environmental, safety, and health risks (Fifth ed.). John Wiley \& Sons, Inc.

McNamara, A. (2020). CDC confirms first case of coronavirus in the United States. CBS News. https://web.archive.org/ web/20200126010915/https://www.cbsnews.com/news/coro navirus-centers-for-disease-control-first-case-united-states/

Morgan, M. G., Fischhoff, B., Bostrom, A., \& Atman, C. J. (2002). Risk Communication: A Mental Models Approach. Cambridge University Press.

Pang, A., Jin, Y., \& Ho, B. M.-K. (2016). How crisis managers define ethical crisis communication practice in Singapore: Identifying organizational factors that influence the adoption of ethical stances. Media Asia, 43(3/4), 191-207. https://doi. org/10.1080/01296612.2016.1276316

Reber, B., \& Cameron, G. T. (2003). Measuring contingencies: Using scales to measure public relations practitioner limits to accommodation. Journalism and Mass Communication Quarterly, 8o(2), 431-446. https://doi.org/10.1177/107769 900308000212

Rhee, Y. (2008). Risk communication management: A case study on Brookhaven national laboratory. Journal of Communication Management, 12(3), 224-242. https://doi. org/10.1108/13632540810899416

Rogers, E. M., \& Kincaid, D. L. (1981). Communications Networks: Toward a New Paradigm for Research. The Free Press.

Rowan, K. E. (1991). Goals, Obstacles, and Strategies in Risk Communication: A Problem-Solving Approach to Improving Communication about Risks. Journal of Applied Communication Research, 19(4), 300-329. http://doi. org/10.1080/00909889109365311

Sandman, P. M. (1987). Risk Communication: Facing Public Outrage. EPA Journal (U.S. Environmental Protection Agency), 21-22.

Schreckinger, B. (2020). Mask mystery: Why are U.S. officials dismissive of protective covering? Retrieved July 15, 2020, from https://web.archive.org/web/20200331122354/https:// www.politico.com/news/2020/03/30/coronavirus-maskstrump-administration-156327 
U.S. Government. (n.d.). U.S. Embassy in Argentina. Retrieved February 21, 2021, from https://web.archive.org/web/2021022 1110352/https://ar.usembassy.gov/education-culture/irc/u-sgovernment

West Virginia Department of Health and Human Resources. (2020). COVID-19 Daily Update March 17, 2020. Retrieved July 15, 2020, from https://web.archive.org/web/20200319 095515/https://dhhr.wv.gov/News/2020/Pages/COVID-19Daily-Update---March-17,-2020.aspx 

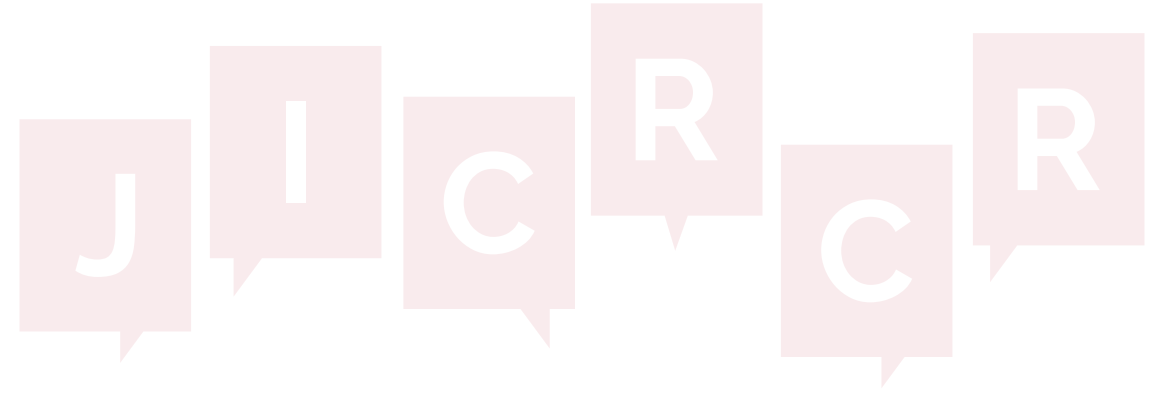